\title{
Dólar, petróleo e novas práticas de comércio internacional
}

\section{Dollar, oil and new practices in international trade}

\author{
BOUZID IZERROUGENE \\ Henrique Tomé DA Costa-Mata*
}

\begin{abstract}
This paper attempts to understand the movements of oil price increase and the American dollar depreciation, between 2001 and 2008. In this conjuncture of uncertainty, the USA suffers from important retraction in economic and geopolitical spheres. American Foreign and budgetary deficits induce an unbalance dynamic which tends to disorder the world economy.
\end{abstract}

Keywords: US unbalances, dollar, euro, oil, China.

\section{Resumo}

Esse trabalho busca entender o significado dos movimentos de alta sustentada do preço do petróleo e de queda rápida da cotação do dólar, entre 2001 e 2008. Naquele contexto de incerteza, a maior potência, Estados Unidos, começou a sofrer de uma importante retração nos planos econômico e geopolítico. Os colossais déficits externo e fiscal estadunidenses passaram a gerar uma dinâmica de desequilíbrio nas finanças internacionais e acentuar os sobressaltos do mundo em transição.

Palavras-chave: desequilíbrios estadunidenses, dólar, euro, petróleo, China.

\footnotetext{
*Universidade Federal da Bahia, Brasil. Correo-e: bouzid@ufba.br, hnrmata@hotmail.com.
} 


\section{Introduçáo}

Com a supremacia do dólar nas transaçóes internacionais, os mercados de capitais e os mercados cambiais ainda estão fortemente dependentes da política monetária dos Estados-Unidos (EUA). Todavia, a generalização do regime de câmbio flutuante no mundo tende a reduzir a importância do dólar na sua função de reserva internacional de valor, em razão da subseqüente multiplicação e diversificaçáo dos mercados cambiais. Nos mercados mundiais de bens e serviços, embora a moeda norte-americana mantenha firme a sua supremacia enquanto unidade de conta, o seu predomínio como meio de pagamento declina também. Mesmo que o dólar seja a moeda de faturamento das commodities em geral, paises como Irá, Venezuela, Rússia e outros não são obrigados a vender seu petróleo em dólar. Podem preferir o euro, suas próprias moedas ou até mesmo o escambo, como no caso das transaçóes comerciais entre o Irã e a China, a China e o Sudão e outras modalidades de comércio cada vez mais significativas. Nessas transaçôes, os valores não se alteram, efetuando-se conforme as taxas cambiais e a cotação das matérias primas em dólar. Somente a demanda por dólares é que acusa uma contraçáo relativa nos mercados monetários, reduzindo os imensos privilégios que os EUA costumam usufruir enquanto emissores da moeda-padrão internacional.

Esse desafio em curso para os EUA vem acoplado de uma situação de crescentes déficits externos e fiscais, cujas condiçóes de financiamento apresentam uma nítida deterioração. Desde então, se coloca a questão da reação das autoridades estadunidenses e de suas conseqüências sobre a economia mundial. A vontade expressa dos norte-americanos em aumentar o seu controle sobre as reservas de petróleo atesta de uma estratégia provada de procurar parte do financiamento dos déficits através do encarecimento do petróleo. Mas essa relação deve contar com a nova dinâmica desencadeada pela expansão da China, um país que se torna, por sua grande capacidade de financiamento e forte penetração nos mercados internacionais, concorrente direto dos EUA, sobretudo nos mercados de commodities, o petróleo em particular.

Para entender o sentido da desvalorização rápida do dólar e da elevação contínua do preço do petróleo entre 2001 e 2008, o artigo pretende examinar a relação econômica e financeira entre as potências econômicas diante das mudanças em curso. Isso supõe uma reflexão sobre a estratégia dos EUA para resolver seus desequilíbrios internos e externos e sobre as conseqüências que essa estratégia possa acarretar em termos de re-ordenamento econômico e político mundial.

Para tanto, serão discutidos, na próxima seção, os desequilíbrios da economia norte-americana, os quais geram uma situação nova de endivi- 
damento e apresentam uma configuração inédita no cenário internacional. $\mathrm{Na}$ terceira seção, serão analisados os ciclos financeiros da década de 2000, destacando-se a ofensiva estadunidense em relação à concorrência européia no sistema monetário internacional, notadamente por meio do encarecimento do petróleo como forma de conter a queda do dólar. A quarta seção será dedicada precisamente à relação entre petróleo e dólar, e mostrará como tradicionalmente o aumento do preço do barril eleva a demanda mundial por ativos em dólar e como essa relação está perdendo vigor nos últimos anos, em virtude das mudanças verificadas nos fluxos internacionais de capitais. Essas mudanças geram uma situação de endividamento profundo dos EUA que mina necessariamente o status hegemônico da moeda norte-americana. A seçáo subsequente terá como objetivo mostrar como os países superavitários da Ásia e os EUA estão condenados a se sustentarem mutuamente, qualificando essa situação de equilíbrio do terror financeiro. Na sexta seção, será analisado o afrouxamento da necessidade de mobilizar dólares para o faturamento internacional, por causa das novas práticas de comércio internacional que restringem o uso do dólar como meio de pagamento. Essas práticas estão sendo amplamente incentivadas pela China, cujas decisôes estão cada vez mais influentes no mercado mundial. Por fim, conclui-se sobre as tendências à mudança na política internacional dos EUA.

\section{Os desequilíbrios estadunidenses - uma configuração inédita}

O considerável e crescente déficit externo dos EUA e a acumulação subseqüente de superávits comerciais na maior parte do resto do mundo constituem um dos paradoxos mais flagrantes da economia mundial nessa era de globalização. Os déficits das transaçóes correntes estadunidenses, que representam a conta comércio exterior e a de transferências de renda, depois que passaram por dois processos de saneamento em 1980 e 1991, persistem numa trajetória de alta constante, gerando uma situação nova de endividamento internacional. A posição externa dos EUA se deteriora nitidamente e o país mais rico do mundo está sendo o maior devedor de todos. O aprofundamento da diferença entre o volume dos haveres norte-americanos e o seu engajamento bruto no mundo ajudou a inverter a tradicional posição favorável à balança de pagamentos dos EUA, quando em 2006 o saldo líquido da conta rendimentos de capitais se tornou negativo, com um déficit equivalente a $2 \%$ do PIB estadunidense (Federal Reserve, 2009). Simplesmente, os EUA recebem mais investimentos do resto do mundo do que investem fora do país e estão se tornando, pela primeira vez na história da hegemonia americana, pagadores líquidos de renda de fatores. Isso significa que a dívida dos EUA 
tenderá a se aprofundar e que o financiamento dos déficits se tornará necessariamente insustentável.

Em 2001, a política econômica estadunidense realizou uma reviravolta total, aplicando uma política monetária e orçamentária expansionista. Através de um processo de grandes dimensões, o banco central dos EUA, o FED, reduziu sua taxa básica de juros de 6,5 para $1 \%$, desencadeando a queda do conjunto das taxas com impacto expansionista sobre a demanda global. Quanto à política fiscal, o confortável excedente de 224,8 bilhôes de dólares que o governo Bush herdou do governo Clinton se transformou logo em déficit. Após o 11 de Setembro de 2001, para evitar a recessão que poderia vir da grave crise de confiança pós-atentados, o governo Bush ampliou gastos e cortou impostos. Isso elevou o crescimento econômico e, claro, gerou um enorme déficit que, logo em 2002, alcançou o nível de 254 bilhōes de dólares, um déficit que irá se acentuar para atingir os 318 bilhóes de dólares em 2006, chegando ao ponto máximo de $4.9 \%$ do Рів. ${ }^{1}$ No ano de 2007, o déficit fiscal norte-americano caiu levemente para 296 bilhôes, mas continua elevado (O Globo, 2008).

No setor externo, o déficit nas contas correntes dos EUA, que era de 413 bilhóes de dólares em 2000, passou para 474 bilhōes em 2002 e continuou na trajetória ascendente, chagando ao nível de 856,7 bilhóes em 2006 (DCA, 2007). Por seis anos consecutivos, as transaçóes correntes registraram um déficit recorde que, em 2006, atingiu US\$ 856,7 bilhões, equivalente a $6.5 \%$ do PIB. Fundamentalmente atrelados à fraqueza da poupança doméstica e ao aprofundamento do déficit público, os desequilíbrios correntes americanos se sustentaram durante mais de quinze anos graças ao apetite dos investidores internacionais pelos títulos americanos, em razáo dos lucros auferidos e, também, devido à situação privilegiada do dólar no comércio mundial. Porém, em razão do desfalque dos capitais europeus nos últimos anos, o financiamento dos déficits americanos passou a contar essencialmente com a intervenção maciça dos bancos centrais asiáticos. Em 2007, o banco da China contribuiu ao financiamento desses déficits por um montante de cerca de um trilhão de dólares (ЕСB, 2007).

Os déficits gêmeos (público e externo) a financiar tomaram dimensões astronômicas de mais de 1,2 trilhão de dólares nos últimos anos. Para o seu financiamento, a economia norte-americana absorve mais de $70 \%$ das transferências mundiais de poupança (Unctad, 2007). Porém, esses fluxos de capital não são suficientes para fechar as contas estadunidenses. A cobertura dos déficits correntes americanos náo passa de $80 \%$ e o hia-

${ }^{1}$ As catástrofes naturais (Katarina e Rita) e a guerra no Iraque acentuaram o déficit público americano em 2006. 
to financeiro chega a um valor de 1,8 bilhão de dólares por dia. Pode-se pensar, nessas circunstâncias, que a queda do dólar se constitui numa variável de ajustamento dos grandes desequilíbrios nas contas externas do país. Os norte-americanos monetizam uma parte dos seus déficits (aquela que não está coberta por capitais estrangeiros), emitindo dólares, o que implica necessariamente a depreciação da moeda americana nos mercados monetários.

A posiçáo do dólar como meio de pagamento e reserva de valor no mundo se viu seriamente afetada após o lançamento do euro, em janeiro de 1999, quando a moeda européia começou a ser usada como uma das variáveis de ajustamento dos desequilíbrios mundiais. Lançada a uma cotação de 1,183 dólar, a moeda européia única se desvalorizou em seguida, atingindo seu nível mais baixo de 0,84 dólar em 2000. No ano subseqüente, o euro reagiu para alcançar a sua taxa mais elevada em dólar, 1,195 , com uma progressão de $40 \%$. Em fevereiro de 2004 , a sua cotação estava em 1,30 dólar e se manteve alta nos anos 2005 e 2006. No dia 8 de novembro de 2007, o euro registrou uma ascensão extraordinária, quando atingiu o recorde de 1,44 dólar. Diante desse cenário de queda da moeda americana, a China e outros paises superavitários tenderam a substituir uma parte de suas reservas (1,44 trilhão de dólares nas reservas chinesas em 2007) em dólar por outras moedas para minimizar as perdas cambiais, o que acentuou a desvalorização da moeda americana.

\section{Gráfico I \\ Euro contra dólar}

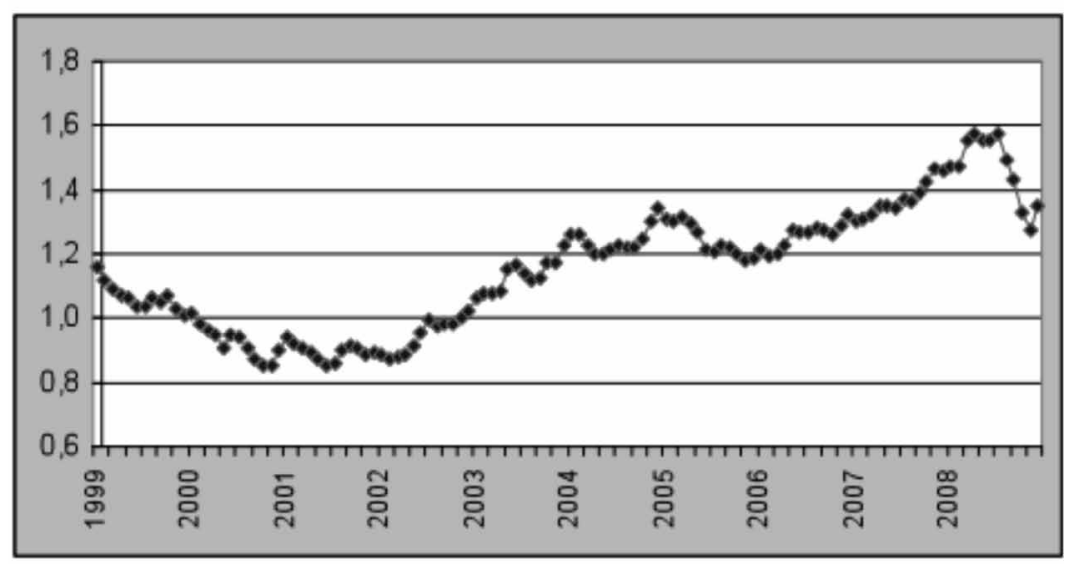

Fonte: Elaboração própria a partir de dados do Banco Central Europeu (2009). 
Os problemas monetário e fiscal não são os únicos que estão em jogo, há também a questáo do preço do petróleo que, desde 1999 até 2008 entrou numa trajetória ascendente. Em outubro de 2004, o barril ultrapassou o limite dos 54 dólares; em agosto 2005, passou para 70,85 dólares; e, em novembro de 2007, chegou a 98,62 dólares, aproximando-se do seu nível recorde registrado em abril de 1980 (101,70 dólares ao preço deflacionado), após a revolução iraniana e durante a guerra Irã-Iraque.

As mudanças cambiais e as políticas monetárias, junto com a conseqüente evolução do preço de petróleo, são variáveis importantes que definem os ciclos financeiros. De 1999 até hoje, a economia mundial passou por dois ciclos financeiros, tendo o ano de 2004 como data de início do segundo.

\section{Os ciclos financeiros da década de 2000}

É importante lembrar a situação econômica nos EUA antes que o FED procedesse ao aperto monetário de 1999 (início do primeiro ciclo). A década de 1990 foi táo proveitosa para a economia americana que alguns comentaristas econômicos evocaram o new age americano. A performance estadunidense havia superado significativamente a de outros paises ocidentais e do Japáo e isso foi explicado pelo sucesso da nova economia e do aumento da produtividade. Com um crescimento econômico relativamente elevado e as contas públicas superavitárias, os capitais asiáticos, árabes e europeus disputavam o ingresso no mercado estadunidense, valorizando o dólar.

Em 1998, a economia mundial entrou numa zona de alta instabilidade. Naquele momento, a oposição conjuntural entre a recessão profunda na qual mergulhavam o Japão e os paises do Sudeste Asiático e o bom vigor aparente das economias européias e dos EUA parecia incoerente com o processo de globalização. A força desestabilizadora da recessão que se propagou ao longo do ano de 1997, partindo do Sudeste Asiático para atingir a Rússia em 1998 e a América Latina, em 1999, foi o resultado, pela primeira vez, de um ataque especulativo à escala global.

Em junho de 1999, o FED procedeu a um aperto monetário para combater a inflação e corrigir os inchaços nominais das bolsas de valores, que foram motivados pelo excesso de capitais. Mas as conseqüências do aumento da taxa de juro nos EUA foram as duas grandes quebras que sofreu Wall Street em abril e setembro de 2000. A procissão de crises financeiras que eclodiram no mundo, no final da década de 1990, marcou o fim de um ciclo financeiro (1994-1998) e abriu espaço para o novo ciclo de 19992004. O início deste novo ciclo coincidiu com a criação do euro. 


\subsection{O primeiro ciclo, junbo 1999-junho 2004}

$O$ início do ciclo. $\mathrm{O}$ euro foi cotado a 1,183 dólar no dia do seu lançamento em janeiro de 1999. A introdução da nova moeda, com cotação acima de 1 dólar, levou alguns analistas a prever uma diversificação das carteiras de títulos internacionais da Ásia, os quais concentram uma grande parte das reservas internacionais. A análise que prevaleceu naquela época e que ainda prevalece hoje é que se os paises asiáticos superavitários determinassem substituir de forma significativa parte de seus haveres em dólar por haveres em outras moedas - para evitar a instabilidade da moeda americana e ampliar suas margens de manobra frente às pressóes econômicas e políticas dos EUA-, o financiamento do crescente déficit da balança de pagamentos americana se complicaria e, a termo, o estatuto de moeda internacional hegemônica do dólar estaria ameaçado.

O euro manteve sua paridade frente ao dólar e o Banco Central Europeu (BCE) aproveitou essa vantagem cambial para rebaixar sua taxa básica de juros de 3 para 2.5\%, em abril de 1999. Mas, dois meses depois, em junho, a Reserva Federal Americana (FED) aplicou uma constrição monetária, aumentando sua taxa básica de 4.75 para 5\%. Era o início do primeiro ciclo financeiro, a partir do qual o FED, em seis vezes consecutivas, havia aumentado sua taxa de juros, a qual chegou ao nível de $6.5 \%$ em maio de $2000 .^{2}$

Nesse tempo, o dólar começou a se valorizar, passando de 1.01 euro, em julho de 1999, para 1.17 euro em outubro de 2000. Em quinze meses, o euro perdeu em torno de $20 \%$ do seu valor frente ao dólar. A sua queda favoreceu as exportaçóes européias, mas inibiu os investidores internacionais que irão preferir os títulos americanos, acentuando assim a queda do euro. O все foi obrigado a aumentar sua taxa básica para limitar a fuga de capitais. No dia 15 de novembro a taxa européia passou a $3 \%$. O preço do barril de petróleo, que era de 10 dólares em janeiro de 1999, aumentou para 14 dólares em abril do mesmo ano, saltando para os 26 dólares em janeiro 2000. Com o encarecimento do petróleo e das demais matérias primas, a inflação importada ameaçava o mercado europeu. No dia 4 de janeiro, o BCE antecipou uma mudança na sua taxa de juros, que foi elevada a $3.25 \%$, dando início a uma serie de altas que culminaram com um nível de $4.75 \%$ no dia 6 de outubro de 2000 . No dia 6 de setembro, a cotação do petróleo atingiu os 36 dólares o barril, enquanto o dólar se manteve entre 1.16 e 1.17 euro.

\footnotetext{
${ }^{2}$ Os dados sobre as taxas de juro americanas são do Federal Reserve (statistical release). Os dados sobre preço de petróleo são da opep (Monthly Oil Market Report). Os dados sobre as taxas de juro européias são do Banco Central da Europa (bce). Os dados sobre as taxas cambiais são dos sites de Internet: www.yahii.com.br/euro.html e www.easy-forex.com/en/.
} 
A estratégia americana de elevar a taxa de juros visava atender a dois objetivos essenciais e associados: atrair os capitais estrangeiros, notadamente europeus, para financiar as transaçōes correntes e, no mesmo tempo, suprir, com esses capitais, a demanda adicional de liquidez em dólar, a qual se devia ao encarecimento das commodities. ${ }^{3} \mathrm{~A}$ reciclagem desses capitais minimiza, em geral, o recurso a uma emissão monetária maciça para assegurar as importações e, ainda, permite manter a força do dólar acima das outras moedas internacionais, sobretudo do euro. No entanto, as elevadas taxas americanas de juro, acopladas a um dólar em alta, prejudicam, não somente os agregados internos (nível fraco de consumo, crédito muito caro para as famílias e empresas), mas também a competitividade da indústria americana. De fato, o dólar caro freou as exportaçóes americanas e, junto com o juro alto, contribuiu para as derrocadas da bolsa de Wall Street em abril e setembro de 2000.

A guinada do ciclo. A elevação das taxas americanas de juro, embora moderada, contraiu o consumo e o investimento domésticos. No primeiro trimestre de 2001, o crescimento da economia americana, que foi de $1.9 \%$ no último trimestre de 2000 , passou para $1.3 \%$ e, em seguida, caiu para $0.7 \%$ no seu ritmo anual, embora o FED tivesse antecipado a recessão desde janeiro de 2001, quando reduziu a taxa básica de 6.5 para $6 \%$, marcando com isso a virada do ciclo. Para reanimar as bolsas de valores, as autoridades monetárias dos EUA procederam a seis reduçóes na taxa básica de juros durante o primeiro semestre, fazendo com que a taxa interbancária (de curto prazo) passasse nesse pouco tempo de 6.5 a $3.75 \%$. Os juros de curto prazo ficaram mais elevados na Europa em relação aos EUA pela primeira vez desde a criação do euro. Depois da tragédia do 11 de setembro de 2001, no mesmo ano em que houve o crash dos valores tecnológicos, a taxa de juro americana de curto prazo sofreu mais cinco cortes no último trimestre de 2001, passando para $1.75 \%$ no final do ano. O processo de contraçáo prosseguiu e, em junho de 2003, a taxa em questão caiu para 1\%, o nível mais baixo desde 1951 .

Do lado europeu, o BCE operou, em maio 2001, isto é, quatro meses depois da intervençấo da FED, um corte de $1 / 4$ ponto percentual na sua taxa básica, a qual havia se mantido estável desde novembro de 1999 (4.75\%). Como nos EUA, a taxa básica européia continuou na trajetória de queda até 2003 , quando chegou a $2 \%$. O contexto de taxas de juro em queda nos dois continentes náo foi suficiente, contudo, para evitar uma redução na taxa de crescimento da economia mundial, mas, com o subsistente diferencial de juros, o euro se fortaleceu e atingiu, no dia 27

\footnotetext{
${ }^{3} \mathrm{O}$ dólar sendo a moeda essencial no mercado internacional de commodities em geral.
} 
de maio de 2003, a barra de 1.19 dólar, acima do seu nível de introdução, em janeiro de 1999.

\subsection{A ofensiva americana $e$ o segundo ciclo financeiro dos anos 2000}

Se a década de 1990 foi estável e confortável para os EUA, a década de 2000 está, em oposição, repleta de inconveniências que ameaçam a posição americana no mercado mundial, o que explica, num primeiro momento, a acentuação da belicosidade dos EUA na política internacional. Qual é o parafuso ruído que alui a máquina lubrificada do Império americano? O grão de areia é precisamente a redução da importância do dólar como moeda internacional: são as crescentes transaçôes internacionais que se efetuam sem o uso do dólar; são os intercâmbios que se realizam entre as naçóes e as firmas transnacionais por outros meios como o euro, as moedas regionais dentro de blocos econômicos e até mesmo via escambo. Daí o interesse do governo americano em dominar as reservas de petróleo no mundo e entregar a sua exploração às firmas americanas, um meio de enfraquecer as moedas que tentam partilhar o privilégio do dólar. Um privilégio que consiste essencialmente em transferir o ônus financeiro dos déficits da economia hegemônica ao resto do mundo.

Os americanos invadiram o Iraque em 20 de março de 2003 e, em três semanas, derrubaram a ditadura do temerário Saddam Hussein, dando um fim a um regime que se atreveu, a partir de setembro de 2000, a faturar em euro suas exportaçóes de petróleo. No dia 2 de maio de 2003, o presidente Bush anunciou precipitadamente o fim da resistência no Iraque e, num clima de euforia, os neoconservadores americanos sugeriam a utilização da mesma força contra a Síria, O Irã e, até mesmo a Arábia Saudita (uma antiga aliada). Na crise que surgiu do unilateralismo americano dentro das Naçóes Unidas estava claro que a ofensiva contra o Iraque obedecia a uma estratégia diferente do pretexto extravagante de que os americanos iriam civilizar os beduínos do Oriente Médio. ${ }^{4}$ Tratava-se mesmo de defender a hegemonia econômica e monetária dos EUA no mundo. Aos paises árabes, majoritários na opep, a invasão do Iraque lhes serviria de aviso contra qualquer pretensão de mudança no plano monetário do petróleo. ${ }^{5}$

\footnotetext{
${ }^{4} \mathrm{O}$ pretexto das armas químicas também não vale, pois os americanos só invadiram o Iraque depois que tiveram a certeza, através dos inspetores da onu que fizeram este trabalho, de que não havia armas de destruição maciça. Nâo teriam corrido tamanho risco.

${ }^{5}$ Não foi por acaso que o governo dos Estados Unidos apresentou uma atitude moderada face ao regime de Pyongyang na Coréia do Norte, o qual rompeu os acordos sobre a energia atômica em dezembro de 2002, enquanto que, face ao Iraque, o mesmo governo de Bush se mostrou altamente intransigente.
} 


\section{Gráfico II \\ Taxa básica de juros nos EUA, 1999-2008}

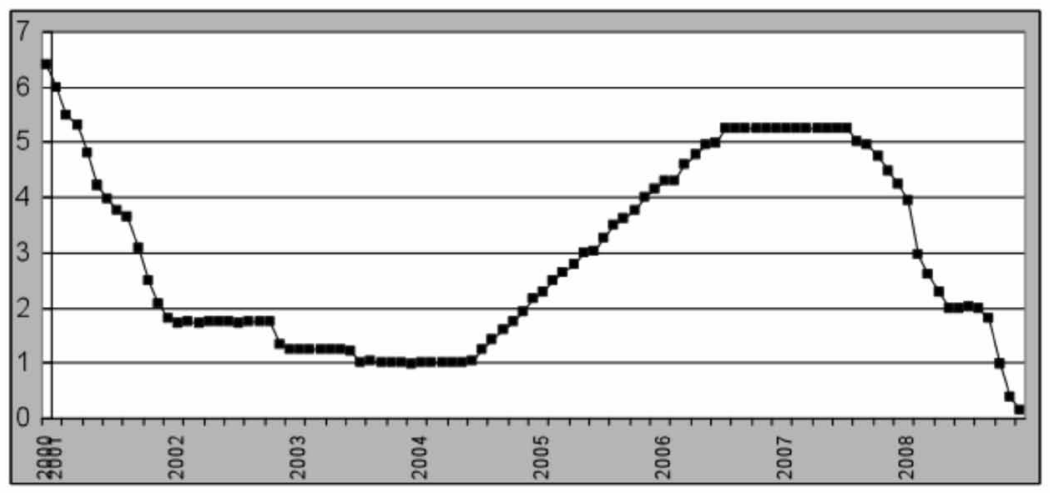

Fonte: Elaboração própria a partir de dados da Federal Reserve System (2009).

No entanto, o que os estratégicos da Casa Branca não previram é que a guerra no Iraque perdurasse e saísse muito mais cara para os cofres públicos americanos, contribuindo assim para a depreciação do dólar. Nos meados de novembro de 2003, a moeda americana registrou a sua mais baixa cotação histórica frente ao euro ( 0.83 euro por 1 dólar). Conseqüentemente, um número importante de investidores internacionais tendeu a aplicar partes crescentes de suas poupanças na Europa, acentuando a desvalorização da moeda americana que, em fevereiro de 2004, caiu para 0.77 euro. Diante disso, em junho, o FED aumenta de 1/4 ponto sua taxa básica, que passou de 1 para 1.25\%. Uma nova fase de ascensão do juro se iniciou entáo, dando lugar ao segundo ciclo financeiro desde a criação do euro em janeiro de 1999. A taxa americana de curto prazo continuou em alta ao longo dos anos 2004 e 2005, alcançando em setembro 2005 o nível de $3.75 \% .{ }^{6}$ Mas isso não foi suficiente para reverter a baixa do dólar, o qual terminou o ano 2004 cotado a 0.74 euro.

A política americana de contração monetária, iniciada em junho de 2004 foi comparada à mesma política que o FED adotou em junho de 1999, quando reverteu o processo de queda na sua taxa básica de juros. Naquela época, a contração monetária obedeceu essencialmente à necessidade de contrair a pressão inflacionária que se deveu ao excesso de liquidez. Mas, em 2004, a conjuntura econômica americana estava diferente, marcada pelo enfraquecimento do dólar, pela redução dos ingressos de capital estrangeiro e pela expansão dos déficits gêmeos. Em junho de 2004, as autoridades monetárias dos EUA, ao elevarem de forma moderada a taxa de

\footnotetext{
${ }^{6}$ Esse crescimento dos juros coincide com a consolidação dos déficits gêmeos americanos. Em 2004, o déficit público americano atinge 422 bilhôes de dólares, e o comercial cerca de 640 bilhôes.
} 
curto prazo, estavam conscientes de que a política monetária, por si só, não era mais suficiente para tornar atraentes os investimentos em dólar, no mesmo tempo em que o controle da inflação não poderia ser garantido sem a volta maciça dos capitais estrangeiros. Havia, portanto, a necessidade de encontrar outro recurso para compensar a falta do financiamento externo. A repatriação dos lucros das firmas americanas, que foi estimulada pelos incentivos fiscais, é limitada e sua realização custosa pesa sobremaneira nas contas pública que estáo profundamente deficitárias.

Parece que o único cenário possível para o novo ciclo, num contexto eleitoral, está nessa estratégia definida pelos EUA e que já está em curso. Ela consiste em reduzir o imposto para contrariar a recessão e modular o preço do petróleo em benefício do dólar. A pressão sobre o preço do barril obrigaria os países importadores de petróleo a aumentar a parte de suas reservas em dólar e enxugar o excesso deste nos mercados monetários. Uma boa parte dos recursos para financiar os déficits americanos irá derivar então do próprio choque de petróleo, o qual gera pressão no sentido de minimizar a depreciação do dólar via aumento da procura pela moeda americana.

Se o primeiro ciclo financeiro da corrente década levou um ano e meio para mudar e se a sua inflexão, em janeiro de 2001, ocorreu numa situação favorável aos EUA (dólar forte, superávit orçamentário), hoje, diante do dólar fraco e dos déficits gêmeos colossais, teria certamente que esperar muito mais tempo para ver o ciclo se inverter. Esse prazo pode diminuir se o preço do barril se sustentar a níveis elevados, na barra dos 100 dólares e se a taxa de juros e os cortes nos gastos públicos estadunidenses forem adequados.

\section{A relação petróleo/dólar. $O$ preço do petróleo e as necessidades de liquidez em dólar}

Explica-se usualmente a relação positiva entre o preço do petróleo e o dólar pelo comportamento de poupança dos paises exportadores de petróleo. Uma elevação do preço do barril aumenta o superávit externo desses países e os excedentes são aplicados em ativos em dólar. Assim, o encarecimento do petróleo aumenta a demanda mundial por ativos em dólar, cujo resultado mais do que compensa a degradaçáo causada pelo encarecimento do petróleo sobre os saldos externos da economia americana: o dólar se aprecia. Mas, hoje, esse mecanismo tende a não funcionar plenamente.

As importaçóes mundiais de petróleo são de cerca de 50 milhóes de barris por dia. Um incremento do preço do barril de 20 dólares, por exemplo, (como foi o caso em 2004 quando o petróleo passou de 40 para 
60 dólares) provoca uma necessidade de liquidez adicional em dólar de 1 bilhão por dia. Esse capital adicional de giro pode dobrar quando são considerados os derivados de petróleo, que são também faturados em dólar. É um volume considerável de liquidez que se adquire essencialmente junto aos paises superavitários: os asiáticos e os árabes que aplicam suas poupanças no mercado financeiro americano, financiando os déficits gêmeos dos Estados Unidos. ${ }^{7}$ A elevação do preço do petróleo que obriga todos os paises importadores a comprar mais dólares para pagar o petróleo, o reembolso das dívidas por parte dos paises árabes e a reciclagem dos excedentes via o financiamento dos déficits americanos formam um triplo motivo para a limitação da depreciação do dólar.

A cotação do petróleo aumentou firmemente desde meados de 1999 até 2008, paralelamente à queda do dólar e à elevação das taxas de juro no mercado americano. Como explicação, evocavam-se a contração dos estoques americanos de petróleo, a demanda elevada, a falta de investimentos no refino, a instabilidade geopolítica no Oriente Médio, etc. Um grande número de analistas argumentavam, ainda, que os déficits nas transaçôes correntes dos EUA eram a verdadeira razão do encarecimento do petróleo.

De 1973 a 1979, período contido entre duas crises energéticas, o preço do petróleo foi multiplicado por 2.1 vezes e o dólar havia se desvalorizado $18 \% .{ }^{8}$ De 2002 a 2007, o preço do petróleo foi multiplicado por 2.6 vezes, ao tempo em que o dólar sofreu uma desvalorização de cerca de $36 \%$, passando de 1.10 para 0.71 euro no final. Essa comparação mostra como se atenuou o papel do encarecimento do petróleo na minimização da desvalorização do dólar, sobretudo a partir de 2005. De fato, nos últimos três anos a relação entre a alta do petróleo e a cotação do dólar se torna nitidamente negativa: enquanto o preço do petróleo se vê em alta constante, passando do nível de 60 a 100 dólares o barril, entre 2005 e 2007, a cotação do dólar sofre quedas importantes, fechando os anos de 2005, 2006 e 2007 com as respectivas cotaçóes de 0.85 euro, 0.76 euro e 0.69 euro.

É verdade que o dólar desvalorizado diminui o valor real do barril de petróleo em outras moedas. No entanto, a valorização do petróleo, no período em pauta, foi bem maior do que a depreciaçáo do dólar, o que resultou em um considerável aumento da fatura energética dos importadores líquidos de petróleo. Quando se compara a cotação média anual do câmbio euro/dólar com o preço do barril de petróleo dos anos de 2002 e

\footnotetext{
${ }^{7}$ No caso dos paises árabes, endividados, uma parte do excedente serve a quitar dívidas e, conseqüentemente, nẫo reintegra o circuito econômico mundial, isto é, a moeda adicional associada ao petróleo é destruída.

${ }^{8}$ Dados calculados em relação ao marco alemão (World Perspective, 2008).
} 


\section{Gráfico III \\ Cotaçóes dólar e petróleo}

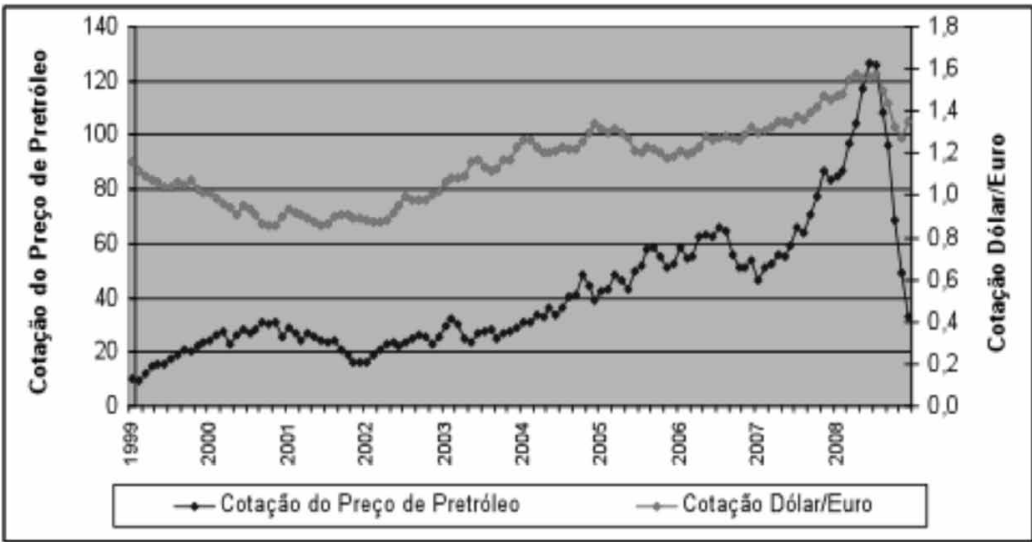

Fontes: Elaboração própria a partir de dados da OPEP (2009) e do BCE (2009).

de 2007, respectivamente um barril a 25 dólares por um euro a 0.94 dólar e um barril a 75 dólares por um euro a 1.36 dólar, pode-se constatar que em 2000 o barril custava 26.5 euros e, em 2007, estava em 55.5 euros: o dobro. Uma verdadeira transferência de poder aquisitivo se operou a favor dos paises exportadores de petróleo.

O encarecimento do petróleo ainda pôde conter a queda da moeda americana, principalmente através da compra de títulos americanos por parte dos países exportadores de petróleo. Sem esses fluxos, cuja principal origem são os paises árabes, o mecanismo não funcionaria e os americanos não teriam nenhum interesse no petróleo caro. Todavia, se os excedentes de petróleo sustentam uma dívida externa americana crescente, em oposição, a permanência dos déficits nas transações correntes dos EUA, junto ao encarecimento do petróleo, suscita necessariamente uma contração da economia mundial e acentua a insustentabilidade desse equilíbrio a termo, provocando uma situação grave para a economia mundial e particularmente para a associação EUA-mundo árabe. A respeito dessa relação, é bom lembrar o que ocorreu em 1986 com o contrachoque petroleiro, quando o preço do barril despencou para 10 dólares. Nessa época, os países árabes exportadores de petróleo estavam profunda e duplamente prejudicados, pois, para agravar mais a sua situação, a queda do preço do petróleo foi acompanhada por uma desvalorização em torno de $100 \%$ do dólar. De fato, o dólar estava muito alto, com a taxa equivalente a 2 euros por 1 dólar, e sua aterrissagem foi concertada, em setembro de 1986, na reunião do G5 (EUA, Japão, Alemanha, Inglaterra e França) no Hotel Plaza em Nova York. A injeção decidida de dólares 
nos mercados monetários foi suficiente para reduzir o valor do dólar pela metade, dispensando os americanos da necessidade de reciclar os excedentes dos países árabes e de pressionar para alta o preço do petróleo. Os déficits estadunidenses na época não ameaçavam a moeda americana, pois eram amplamente financiados por fundos europeus e japoneses. A economia mundial estava em recessão e o desemprego na Europa estava registrando as taxas mais altas da história. A retomada do crescimento se tornou crucial para sair da crise e a queda do preço da energia, um requisito imposto pela conjuntura, o que explica o acordo do Hotel Plaza.

O forte aumento do preço do petróleo nos anos 2000-2008 não provocou contração no ritmo do crescimento da economia mundial. A situação foi, portanto, diferente daquela que prevaleceu durante as crises energéticas dos anos de 1970 e 1980, quando a economia mundial era inflacionária. Por 80 dólares o barril, o calculo dava para a China, por exemplo, um custo energético adicional de 61,55 bilhóes de dólares em 2005 , equivalente a $3.5 \%$ do PIB chinês daquele ano. Isso teria como conseqüência um crowding out de $1.75 \%$, segundo a simulação do Observatório Francês de Conjuntura Econômica (ofCE, 2006). Um ponto do PIB em custo adicional na conta petróleo teria um impacto de $-1 / 2$ ponto no crescimento econômico, o que teria reduzido o crescimento da China para $6.25 \%$ em 2006, taxa inferior à taxa efetiva de $10.7 \%$. A diferença pode encontrar explicação nas vantagens comparativas da China e nas novas estratégias comerciais e de abastecimento aplicadas por este país. Nessas estratégias tenta-se evitar ao máximo a utilização do dólar nas transaçóes comerciais, mesmo que as cotaçóes se referem ainda nominalmente à moeda americana.

Hoje, a situação está diferente, devido, também, à mudança nos fluxos internacionais de capitais, a qual reordena o sistema internacional de endividamento, onde os Estados Unidos são devedores e os paises asiáticos credores. Uma situação de endividamento profundo que mina necessariamente o status hegemônico da moeda americana.

\section{Enfraquecimento do dólar, Bretton Woods II e equilíbrio do terror financeiro}

São os países asiáticos e, numa certa medida, os países árabes exportadores de petróleo que financiam os déficits externos americanos. As intervençôes cambiais dos bancos centrais asiáticos para sustentar o dólar deram mais impulso às importaçóes americanas, particularmente de produtos asiáticos de baixo valor unitário. Freqüentemente, os asiáticos condicionam suas concessóes de empréstimos à conquista de mercados nos países financiados, o que eleva suas exportaçóes para os países que se 
endividam, particularmente os EUA. Para os países árabes, embora as informaçóes sobre seus investimentos diretos não estejam claras, pode-se considerar que sua situação seja semelhante a que associa a Ásia aos EUA. Quanto aos europeus, acanhados, relutam em comprar ativos americanos. Estão duplamente incomodados pela supervalorização do euro e pelo encarecimento desproporcional do petróleo. $\mathrm{O}$ вСE náo sabe como agir para corrigir o câmbio sem gerar mais inflação. Fica, então, na expectativa de uma solução externa, confinado na sua função de garantir a estabilidade dos preços e, com o encarecimento das matérias primas, sustenta o juro para contrariar a inflação importada, agindo de forma pró-cíclica.

Uma interpretação ao aparecimento desses desequilíbrios e de uma possível mudança no sistema monetário internacional foi dada pelos economistas do Deutsche Bank (Folkerts et al., 2007). Segundo essa equipe, influente na literatura sobre as finanças internacionais, o sistema mundial atual pode ser visto como um novo Bretton Woods. Um conjunto de países do Leste Asiático, incluindo a China, aplicam um regime cambial fixo ou quase fixo em relação ao dólar, formando um sistema monetário padrão-dólar informal. Como no regime original de Bretton Woods, os EUA representam o centro que se beneficia do privilégio de emitir a principal moeda-de-reserva internacional, que os países da periferia desejam adquirir a fim de acelerar o seu desenvolvimento. Essa tese se inspira, é claro, da época do pós-guerra, quando as economias da Europa e do Japão estavam em ruínas e se recuperavam dolorosamente da segunda grande guerra; suas moedas estavam desvalorizadas e inconversíveis. Somente o valor do dólar estava garantido pela conversibilidade em ouro, por uma taxa fixa. Algumas semelhanças podem ser observadas entre os dois esquemas monetários, é verdade, mas as diferenças são grandes e suas conseqüências diferentes. No sistema original de Bretton Woods, contrariamente ao sistema atual, a economia americana estava amplamente superavitária. No pós-guerra eram os americanos que exportavam capital e hoje são importadores líquidos.

Segundo Larry Summers, ministro das finanças no governo Clinton, a Ásia e os EUA estão condenados a se sustentarem mutuamente, qualificando essa situação de equilíbrio do terror financeiro. Os asiáticos estariam pressionados a prosseguir na compra dos títulos americanos, apesar do risco cambial crescente dos engajamentos em dólar. Uma atitude contrária pode levar a um crash financeiro desastroso para o mundo e do qual os países credores da Ásia sairiam como principais vítimas (Summers, 2007).

Os EUA acusam a China de manter artificialmente sua moeda desvalorizada para expandir as exportaçóes. Os europeus, depois da forte valorização do euro em outubro de 2007, tentam, também, pressionar a China para elevar o valor do yuan. Todos são unânimes a afirmar que o 
yuan não reflete os fundamentos econômicos da China e pedem uma maior flexibilidade no regime cambial desse país. É verdade que o boom econômico chinês devia elevar o valor do yuan nos mercados cambiais, mas a fragilidade do sistema financeiro da China, junto com o receio de reduzir as exportaçóes e a taxa do crescimento econômico, faz com que as autoridades chinesas mantenham uma política cambial cautelosa, o que acentua os déficits comerciais da Europa e, particularmente, dos EUA junto a China.

Em 2006, a economia americana registrou um déficit comercial recorde de 764 bilhóes de dólares, dos quais 232 bilhóes (mais de 1/4) foram registrados junto a China e 88 bilhóes junto ao Japão, um montante que deve suscitar também a idéia da sub-valorização do iene. ${ }^{9} \mathrm{Na}$ realidade, não há provas de que a apreciação do yuan, de modo a adaptar sua cotação aos fundamentos chineses, contenha as exportaçóes da China e reduza de forma satisfatória os desequilíbrios internacionais. Primeiro, porque a vantagem da China no comércio mundial deriva essencialmente do custo baixo da sua mão de obra, com um salário médio por hora trabalhada de 0.50 dólar, contra 16 dólares nos EUA. Segundo, porque os desequilíbrios americanos têm como foco principal o excesso de gastos públicos, particularmente os gastos militares. ${ }^{10}$ Terceiro, um outro fator de instabilidade americana é a debilidade da poupança doméstica, como prova a crise imobiliária atual. Portanto, um yuan desvalorizado é apenas um dos fatores que alimentam a dinâmica dos desequilíbrios americanos e mundiais. ${ }^{11}$

O embaraço da hegemonia monetária americana está precisamente na contração do papel do dólar nos mercados internacionais, principalmente enquanto meio de pagamentos e reserva de valor, comprometendo a relação positiva entre o preço das commodities e o dólar. Dois fatores interligados explicam a tendência à redução da importância do dólar: o primeiro é que, como já foi dito, muitos países optam por efetuar suas transaçóes comerciais internacionais com suas próprias moedas, com o euro ou com a troca direta de mercadorias e serviços por outras mercadorias e outros serviços. Conseqüentemente, afrouxa-se a necessidade de mobilizar dólares para o faturamento internacional, contraindo assim os investimentos em ativos americanos.

O segundo fator está no surgimento da China no mercado monetário mundial, um país que se tornou, a partir de marco de 2006, o maior de-

${ }^{9}$ Em relaçáo a Europa, os EUA conseguiram, com a valorizaçáo do euro, reduzir o seu déficit para 116.6 bilhóes de dólares, no ano de 2007.

${ }^{10}$ A manutençáo de 737 bases militares pelo mundo exige orçamentos colossais, sem contar as guerras realizadas a partir de 2001.

${ }^{11}$ Ademais, o governo chinês aplica uma política cambial que lhe convém, da mesma forma que as autoridades americanas manipulam, e sempre manipularam o dólar conforme os seus interesses nacionais. 
tentor de reservas internacionais. Praticando um regime cambial quase fixo em relação ao dólar, a China está induzida a se opor à apreciação da moeda americana. Uma diversificação de suas reservas cambiais que pudesse provocar a desvalorizaçáo da moeda americana garantiria a sua competitividade no mercado mundial. Outros países podem seguir o exemplo da China de se desengajar em dólar. ${ }^{12}$ Pode-se entender assim o fim da relação positiva entre a alta das commodities e o comportamento do dólar.

\section{A crescente importância da China no mercado mundial e as novas práticas de comércio internacional}

Há mais de 20 anos a economia chinesa cresce a uma taxa média anual de 9 a $10 \%$, em contraste com o fraco desempenho da economia ocidental, sobretudo a européia. Os americanos, que cresceram durante os últimos 20 anos a uma taxa que flutuou entre 3 e $4 \%$, gastaram mais do que produziram. O sucesso da China ficaria sem explicação se a abertura de sua economia não contasse com uma mão de obra pletórica, qualificada e barata. Graças ao surto econômico, o Império-do-Meio atrai cada ano volumes consideráveis de investimento direto. A moeda chinesa está ancorada a uma cesta de moedas constituída essencialmente pelo dólar americano e a depreciação deste favorece a competitividade da China. Com seus excedentes comerciais extraordinários, a China acumula grandes reservas cambiais, que chegam à cerca de 1.5 trilhóes de dólares em meados de 2007.

Além da inflação, o problema que pode ameaçar a prosperidade chinesa é a escassez na oferta mundial de matérias primas, sobretudo da energia, sendo a China o segundo maior importador de commodities após os EUA. A oferta nacional de energia nesse país, realizada à base do carvão, cobre apenas a metade da demanda e sua participação no mercado doméstico está em queda, razão pela qual as importaçôes estão crescendo significativamente. No entanto, a China mostra praticar uma estratégia de abastecimento energético seguro e diversificado, junto a países diferentes como Arábia Saudita, Irã, Indonésia, Rússia e paises da África e da Ásia central. A penetração chinesa na África e no Golfo pérsico fica cada vez mais precisa. O Sudão e, particularmente, o Irã, dois países que os EUA ameaçam invadir se tornaram parceiros privilegiados da China. ${ }^{13}$ Em troca de petró-

${ }^{12} \mathrm{O}$ banco central da Suécia (Riksbank) procede, desde abril de 2006, a uma diversificação de suas reservas a favor do euro e contra o dólar, quando a proporção da moeda européia aumentou de 37 para $50 \%$ e aquela da moeda americana caiu de 37 a $20 \%$.

${ }^{13}$ A China é o primeiro cliente do Sudão e do Irã. Os chineses se declararam contra o embargo americano contra o Sudão, sustentando o regime de Cartum na questão do Darfur. São também contrários a qualquer intervenção americana no Irã. 
leo com Irã, Nigéria, Angola e Sudão, a China exporta bens e tecnologias. ${ }^{14}$ As empresas petroleiras chinesas, todas estatais, entram em concorrência direta com as majors americanas, atuando até mesmo em áreas petroleiras de predomínio americano, como na Arábia Saudita onde negociam a formação de estoques de petróleo saudita na China.

$\mathrm{Na}$ África, a presença chinesa é mais sentida. As importaçóes da China do continente africano cresceram, em 2006, a uma taxa de $25 \%$, contra $15 \%$ em 1986. Os chineses procedem com extrema atenção na sua política de garantir o abastecimento energético sem ferir os interesses americanos e europeus nas regióes onde estabelecem contratos. A estratégia chinesa nesses contratos, que são de longo prazo, consiste em adquirir petróleo investindo nos setores energéticos e na infraestrutura dos países fornecedores. Essa estratégia se traduz por uma atividade sustentada para as empresas chinesas de construção e engenharia civil, as quais arrebatam as licitaçóes públicas no mundo, em virtude dos custos mais baixos que se devem basicamente à mão de obra qualificada e barata deslocada da China. Freqüentemente, os chineses financiam as obras dos seus parceiros africanos e asiáticos sem cobrar juros, ${ }^{15}$ tendo o reembolso garantido através do fornecimento em petróleo e outras commodities.

Quando são considerados os prejuízos causados por um dólar instável, a venda de matérias primas em outras moedas, ou em troca de mercadorias e serviços, se revela mais benéfica do que quando se recorre à intermediação do dólar. É o que desvenda a política de parceria estratégica pregada pela China. Outros países, em número crescente, tendem também a praticar políticas comerciais que dispensam o dólar como meio de pagamentos, substituindo a moeda americana por acordos bilaterais.

Os chineses preferem praticar escambo com seus parceiros africanos e orientais e restringem o uso do dólar em seus contratos para evitar as oscilações cambiais. Países como Rússia, Venezuela, Irã, Bolívia e Sudão (hostis aos EUA) e outros como a Noruega trocam parte de seus produtos energéticos, ou por outra moeda que não seja o dólar, ou por outras mercadorias ou serviços, mesmo que as cotações e os valores continuem a se referir à moeda americana. Embora continue a ocupar um papel central como unidade de conta, a moeda americana deixa de ser utilizada como meio de pagamentos e reserva de valor nessas novas relaçóes comerciais, as quais tendem a reduzir a procura por dólares, contrair o volume dos excedentes em dólar que regressam aos EUA e privar este país de uma parte do seu direito de senhoriagem sobre o mundo.

\footnotetext{
${ }^{14}$ Particularmente armamentos no caso do Irâ.

${ }^{15}$ A China perdoou a dívida de 31 paises africanos.
} 


\section{Consideraçóes finais}

O dólar está desvalorizado e o preço das commodities no mercado mundial se sustenta. A conta energética continua alta, e as exportações aos EUA, devido à recessão, se contraem, inibindo o crescimento da economia mundial. Desde então, o financiamento de parte dos déficits americanos através do encarecimento do petróleo e das commodities em geral tende a se inviabilizar. Diante desses desafios, o governo americano entende que a situação de desequilíbrio de suas contas ameaça a sua hegemonia monetária. Uma reação ortodoxa das autoridades dos EUA consistiria numa política fiscal e monetária contracionista. Porém, o governo estadunidense tenta debelar a recessão através de uma política fiscal expansionista.

A aplicação dessa política implica necessariamente cortes nas despesas militares. Isso explicaria a mudança de política internacional dos EUA. De fato, o governo estadunidense está mostrando uma vontade de renovar suas políticas pragmáticas, apontando para a aplicação das recomendações do relatório Hamilton-Baker de janeiro de 2007. Ele já mostra uma mudança de atitude no dossiê do Oriente Médio, entendendo que Israel não poderá constituir um apoio sustentável no longo prazo nos novos contornos que se desenham nos cenários geopolíticos e geoeconômicos mundiais. As tropas americanas estáo saindo do Iraque; no Afeganistão, aumenta a participação de outros países ocidentais; na Coréia do Norte, a negociação política substitui a invectiva e gera resultados importantes em termo de redução das instalaçóes nucleares. Todas essas mudanças na política internacional dos EUA apontam para a gestação de uma nova configuração mundial, cuja consolidação dependerá da inteligência estratégica para administrar os fracassos americanos dos últimos anos, pois se trata bem de fracassos frente aos sobressaltos de um mundo em transição.

\section{Referências bibliográficas}

BCE (Banco Central Europeu) (2009), Euro foreign exchange reference rates <http://www.ecb.int/stats/exchange/eurofxref/>, acesso dezembro 2009.

Base de dados (2008) <http://www.yahii.com.br/euro.html>, acesso janeiro 2009.

Base de dados, (2008) <http://www.easy-forex.com/en/>, acesso setembro 2008 . 
DCA (Departamento de Comércio Americano) (2007), Economic Indicators <www.esa.doc.gov/ei.cfm>, acesso março 2008.

ЕСв (European Central Bank) (2009), Euro foreign exchange reference rates, <http://www.ecb.int/stats/exchange/eurofxref/>, acesso abril 2010 .

Federal Reserve (2009) Statistical Release, <http://www.federalreserve.gov/ releases/g5a>, acesso março 2010.

Folkerts-Landau, David, Michael P. Dooley e Peter M. Garber (2007), "The Two Crises of International Economics", NBER Working Paper, n. W13197, New York, <http://papers.ssrn.com/sol3/ papers.cfm?abstract_id=997553>.

O Globo (2008) <http://oglobo.globo.com/>, Rio de Janeiro, acesso fevereiro 2009.

OFCE (Observatoire Français de Conjoncture Economique) (2006), Indicateurs \& Prévisions, Sciences Po., Paris.

Opep (2009), Monthly Oil Market Report <http://www.opec.org/home/ Monthly\%>, acesso janeiro 2010.

Summers, "Larry" Lawrence (2007), "Wake up to the dangers of o deepening crisis", The Financial Times, pp. 25-11.

UNCTAD, World Investment Report (diferentes anos), <http://www.unctad. org/Templates/Page.asp?intItemID=1465>, vários acessos.

World Perspective (2008) <http://perspective.usherbrooke.ca/bilan>, acesso janeiro, 2009.

Recibido: 25 de enero de 2008. Reenviado: 21 de octubre de 2010. Aceptado: 13 de diciembre de 2010.

Bouzid Izerrougene. Possui graduação em Economia-Université de Paris XIII (1984), mestrado em Economia, Universite de Paris XIII (1987), doutorado em Economia, Université de Paris XIII (1992) e pós-doutorado pela Universidade Paris-Dauphine. Atualmente é professor associa- 
do da Universidade Federal da Bahia. Tem experiência na área de Economia, com ênfase em Teoria do Comércio Internacional, Economia Monetária e Economia da Cultura e do Conhecimento. Publicou artigos científicos em periódicos especializados, livros e capítulos de livros. Realizou comunicaçôes científicas em eventos nacionais e internacionais. É membro do Conselho Editorial das Revistas Análise \& Dados, Revista de Economia do Nordeste e Nexos Econômicos. É membro de comissóes científicas dos Encontros da Associação Nacional de Pós-Graduação em Economia (ANPEC) e da Economia Baiana. Últimas publicaçôes: A Instabilidade das Finanças Internacionais e a Vulnerabilidade das Economias Periféricas, ufBA, Salvador (2000); "Les Principaux Défis de l'Integration Economique de Pays inégalement développés”, em Isabelle Hannequart, (org.), Union Europeenne e Mercosud. Entre Concurrence e Solidarité, L'Harmattan, Paris, pp. 301-321 (2008); co-autoria, "A Lógica da acumulação capitalista na economia informacional”, Liinc em Revista, 6, São Paulo, pp. 41-65, <http://revista.ibict.br/liinc/index.php/liinc/article/ view/339> (2010).

Henrique Tomé da Costa-Mata. Tem graduação em Engenharia Florestal pela Universidade Federal Rural de Pernambuco, Brasil (1990), Licenciatura em Ciências Agrícolas pela Universidade Federal Rural de Pernambuco, Brasil (1990), com estágio supervisionado na área de administração rural. Possui Mestrado em Ciências Florestal (Economia Florestal) pela Universidade Federal de Viçosa, Brasil (1993), com dissertação no campo de socioeconomia de demanda de energia residencial em áreas rurais de produção florestal destinadas à indústria de papel e celulose. Tem Doutorado em Economia Aplicada pela Universidade Federal de Viçosa, Brasil (2001), com tese sobre teoria econômica e meio ambiente (macroeconomia ambiental). Atualmente é professor adjunto na Universidade Federal da Bahia, Departamento de Teoria Econômica. Tem experiência no campo de gestão de Recursos Naturais, Meio Ambiente e Desenvolvimento. No campo do ensino, ministra disciplinas de teoria econômica em geral, microeconomia, macroeconomia e economia dos recursos naturais e meio ambiente, com enfoque na pesquisa sobre políticas de desenvolvimento e meio ambiente. Últimas Publicaçôes: en coautoria, "Caracterização e dinâmica dos mecanismos de incentivo ao desenvolvimento do Pólo Digital de Pernambuco", Revista Desenbahia, 7, Salvador, pp. 163-188 (2010); "A economia política do desenvolvimento em África: Reflexôes com base em agregados econômicos de países lusófonos e francófonos", em Lívio Andrade Wanderley, Osmar Sepúlveda Gonçalves (org.), Reflexóes dos economistas baianos, 2007-2008, Saraiva, Salvador, pp. 107-124 (2008); “Interpretação da Lei Kaldor-Verdoorn 
para Análise Setorial do PIB, Valor Adicionado, Produtividade e Emprego na Economia Brasileira" em Fernando Rios do Nascimento (org.), 40 Anos do Curso de Economia: Memória, 2, ed. revista e ampliada, Editora da UESC, Ilhéus, pp. 423-450 (2006). 